\title{
Article
}

\section{Design and Synthesis of Ranitidine Analogs as Multi-Target Directed Ligands for the Treatment of Alzheimer's Disease}

\author{
Jie Gao ${ }^{1, *}$, Chen Suo ${ }^{2}$, Jui-Heng Tseng ${ }^{2}{ }^{\oplus}$, Melissa A. Moss ${ }^{2}$, Alvin V. Terry, Jr. ${ }^{3}$ and James Chapman ${ }^{4}$ \\ 1 Department of Clinical and Diagnostic Science, University of Alabama at Birmingham, \\ Birmingham, AL 35294, USA \\ 2 Department of Chemical Engineering and Biomedical Engineering, University of South Carolina, \\ Columbia, SC 29208, USA; suochen@crc.com.hk (C.S.); tsengj@neurology.unc.edu (J.-H.T.); \\ mossme@cec.sc.edu (M.A.M.) \\ 3 Department of Pharmacology and Toxicology, Augusta University, Augusta, GA 30912, USA; \\ aterry@augusta.edu \\ 4 Department of Discovery and Biomedical Sciences, University of South Carolina, Columbia, SC 29208, USA; \\ chapman@cop.sc.edu \\ * Correspondence: gaoj@uab.edu
}

Citation: Gao, J.; Suo, C.; Tseng, J.-H.; Moss, M.A.; Terry, A.V., Jr.; Chapman, J. Design and Synthesis of Ranitidine Analogs as Multi-Target Directed Ligands for the Treatment of Alzheimer's Disease. Int. J. Mol. Sci. 2021, 22, 3120. https://doi.org/ $10.3390 /$ ijms 22063120

Academic Editor: Chakraborty Ashok

Received: 19 February 2021

Accepted: 16 March 2021

Published: 18 March 2021

Publisher's Note: MDPI stays neutral with regard to jurisdictional claims in published maps and institutional affiliations.

Copyright: (c) 2021 by the authors. Licensee MDPI, Basel, Switzerland. This article is an open access article distributed under the terms and conditions of the Creative Commons Attribution (CC BY) license (https:// creativecommons.org/licenses/by/ $4.0 /)$.

\begin{abstract}
The aggregation of amyloid $\beta(\mathrm{A} \beta)$ peptides and deposition of amyloid plaques are implicated in the pathogenesis of Alzheimer's disease (AD). Therefore, blocking $A \beta$ aggregation with small molecules has been proposed as one therapeutic approach for AD. In the present study, a series of ranitidine analogs containing cyclic imide isosteres were synthesized and their inhibitory activities toward $A \beta$ aggregation were evaluated using in vitro thioflavin T assays. The structureactivity relationship revealed that the 1,8-naphthalimide moiety provided profound inhibition of A $\beta$ aggregation and structural modifications on the other parts of the parent molecule (compound 6) maintained similar efficacy. Some of these ranitidine analogs also possessed potent inhibitory activities of acetylcholinesterase (AChE), which is another therapeutic target in AD. These ranitidine analogs, by addressing both $\mathrm{A} \beta$ aggregation and $\mathrm{AChE}$, offer insight into the key chemical features of a new type of multi-target directed ligands for the pharmaceutical treatment of AD.
\end{abstract}

Keywords: Alzheimer's disease; amyloid $\beta(\mathrm{A} \beta)$ aggregation; acetylcholinesterase; multi-target directed ligands; naphthalimide; thioflavin $\mathrm{T}$

\section{Introduction}

Alzheimer's disease (AD) is the most common form of dementia in the elderly population. One of the main pathological hallmarks in AD is the extracellular amyloid $\beta$ $(\mathrm{A} \beta)$ plaques, which deposit between neurons, disrupt neural functions, and contribute to neuronal death [1]. The A $\beta$ plaques are formed by the aggregation of polymorphous $A \beta$ monomers. In particular, $A \beta_{40}$ and $A \beta_{42}$ are prone to aggregate into various assemblies [2,3]. Therefore, the prevention of aggregation of these monomers is considered to be a promising therapeutic approach for AD therapy.

The dipeptide Phe19-Phe20 in the A $\beta$ monomeric structure has been reported to play a critical role in aggregation [4]. A derivative structure from this dipeptide, two aromatic end groups connected by a linker, has been proposed to act as an ideal scaffold for an $\mathrm{A} \beta$ aggregation inhibitor by disrupting the $\pi-\pi$ stacking between $\mathrm{A} \beta$ monomers through interaction with the phenylalanine residues 19 and 20 [5]. Several molecules derived from this structure have shown potent inhibition of $A \beta$ aggregation [6-8].

Most of the current pharmaceutical treatments for AD are acetylcholinesterase (AChE) inhibitors. Unfortunately, these currently approved drugs have been found to benefit only about half the individuals who take them and to only temporarily decrease symptoms [9]. It is now well recognized that $\mathrm{AD}$ is multifactorial in nature, therefore, Cavalli A. et al. [10] 
proposed "multi-target-directed ligands" (MTDLs) for the treatment of AD. MTDLs describe single compounds "that interact with the multiple targets thought to be responsible for disease pathogenesis" [10]. MTDLs might present a feasible avenue to provide optimal therapeutic effects in $\mathrm{AD}$.

In one of our previous studies, a series of ranitidine analogs containing cyclic imide isosteres were synthesized as cognitive enhancers for the treatment of AD. A 3-nitro1,8-naphthalimide derivative (compound 6, Figure 1) was found to be a potent AChE inhibitor with $\mathrm{IC}_{50}=0.15 \mu \mathrm{M}$. [11]. It is interesting that the structures of these ranitidine analogs conform to the proposed ideal scaffold of $A \beta$ aggregation inhibitors. This study employed compound $\mathbf{6}$ as a prototypical compound for the development of a new series of compounds inhibiting both acetylcholinesterase and $\mathrm{A} \beta$ aggregation simultaneously as MTDLs for the treatment of AD.<smiles>CC1CC(=O)N(CCSCc2ccc(CN(C)C)o2)C1=O</smiles>

1<smiles>[R]c1cc2c3c(cccc3c1)C(=O)N(CCSCc1ccc(CN(C)C)o1)C2=O</smiles>

3: $\mathbf{R}=\mathbf{H}$

6: $\mathrm{R}=\mathrm{NO}_{2}$<smiles>[R2]c1ccc2c(c1[R])C(=O)N(CCSCc1ccc(CN(C)C)o1)C2=O</smiles>

2: $\mathbf{R}_{\mathbf{1}}=\mathbf{H}, \mathbf{R}_{2}=\mathbf{H}$

4: $\mathrm{R}_{1}=\mathrm{NO}_{2}, \mathrm{R}_{2}=\mathrm{H}$

5: $\mathrm{R}_{1}=\mathrm{H}, \mathrm{R}_{2}=\mathrm{NO}_{2}$

Figure 1. The structure of ranitidine analogs containing cyclic imide isosteres.

\section{Results and Discussion}

2.1. A Monomer Aggregation Inhibition by Ranitidine Analogs Containing Cyclic Imide Isosteres

Synthetic $A \beta_{40}$ was used in this study because it is the predominant isoform found in amyloid plaques isolated from AD brain [12]. Thioflavin T (ThT), a fluorescent compound that binds specifically to amyloid $\beta$-sheet structures to yield a shifted, enhanced florescence, was used to monitor the appearance of aggregates. Aggregation of $A \beta$ monomer was observed to follow the expected trend, including a lag time to aggregate formation, aggregate growth, and an equilibrium plateau (Figure 1, control). The inhibitory effect of compounds on $A \beta$ aggregation was evidenced as a reduction in the equilibrium plateau and/or an increase in the lag time [13]. The plateau reduction (Figure 2A), which indicates inhibition that reduces the extent of $A \beta$ aggregation, was defined as the percentage decrease of the plateau ThT fluorescence in the presence of inhibitor, P2, compared to the plateau ThT fluorescence in the absence of inhibitor, P1. The lag time extension (Figure 2B), which indicates inhibition during the early stages of $A \beta$ aggregation, was determined as a fold increase of the time at which ThT fluorescence is first observed in the presence vs. absence of inhibitor, $\mathrm{T} 2$ and $\mathrm{T} 1$, respectively. 

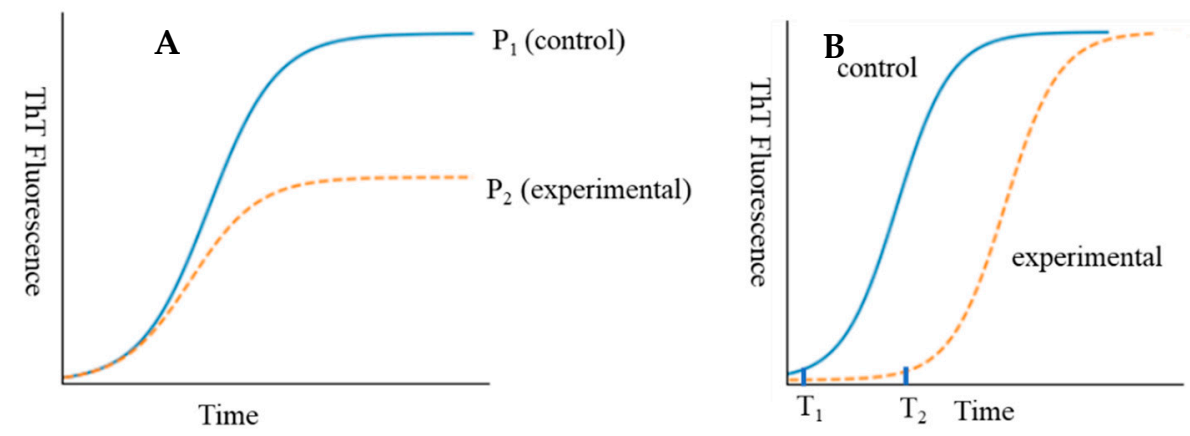

Figure 2. Assessment of the inhibition of $A \beta$ monomer aggregation. Monomer aggregation assays were conducted in the absence (solid line, control) and presence (dotted line, experimental) of the ranitidine analogs, and aggregate formation was monitored as an increase in the ThT fluorescence. (A) Inhibition that decreases the quantity of aggregates formed at equilibrium is reported as the plateau reduction, the percentage decrease of the plateau ThT fluorescence in the presence of inhibitor, P2, compared to the plateau for the control, P1. (B) Inhibition that extends the time to aggregate formation is reported as the lag time extension. It is evidenced as an increase in the experimental lag time, $\mathrm{T} 2$, relative to the lag time for the control, $\mathrm{T} 1$, and evaluated as a fold increase relative to the control, T2/T1.

As shown in Table 1, all ranitidine analogs containing cyclic imide isosteres have an aromatic furan group at one end of their structures, while the number of aromatic rings at the other end of structures vary from $0-2$. The plateau reductions by compounds 1-3 were improved as the number of fused unsubstituted aromatic rings increased on the cyclic imide moiety. Compound 3 with a 1,8-naphthalimide group presented a substantial plateau reduction of $60.9 \% \pm 5.7 \%$. This result preliminarily indicates that pronounced plateau reduction of $A \beta$ aggregation might require at least two aromatic rings fused to the cyclic imide. The addition of a nitro group on an aromatic ring might be able to enhance the plateau reduction, as evidenced by compound $5 \mathrm{vs.} 2$ as well as compound $6 \mathrm{vs}$. 3. It should be noted that the position of the nitro group on the aromatic ring might be critical since the 2-nitro substitution in compound 4 does not improve the plateau reduction, while the 3-nitro substitution in compound 5 demonstrates a plateau reduction of $39.1 \% \pm 19.2 \%$. In addition, the cyclic imide with no fused aromatic rings (compound 1) exhibits a lag extension of $2.8 \pm 0.6$-fold. This mode of inhibitory capability is lost with the addition of fused unsubstituted aromatic rings (compounds 2 and 3). However, some extension of the lag is regained with the addition of a 3-nitro group (compound 5). Since the 1,8-naphthalimide derivatives (compound 3 and 6 ) demonstrate the most potent plateau reduction among these series of compounds, the 1,8-naphthalimide group is favorable in these ranitidine analogs to inhibit $A \beta$ aggregation.

Table 1. The A $\beta$ monomer aggregation inhibitory capability of compounds $1-\mathbf{6}^{\mathrm{a}}$.

\begin{tabular}{ccc}
\hline Compound & $\begin{array}{c}\text { Plateau Reduction } \\
\text { (\% Inhibition) }\end{array}$ & $\begin{array}{c}\text { Lag Time Extension } \\
\text { (Fold Increase) }\end{array}$ \\
\hline $\mathbf{1}$ & N.E. & $2.8 \pm 0.6$ \\
$\mathbf{2}$ & N.E. & N.E. \\
$\mathbf{3}$ & $60.9 \% \pm 5.7 \%$ & N.E. \\
$\mathbf{4}$ & N.E. & N.E. \\
$\mathbf{5}$ & $39.1 \% \pm 19.2 \%$ & $2.0 \pm 0.6$ \\
$\mathbf{6}$ & $71.8 \% \pm 3.9 \%$ & N.E. \\
\hline
\end{tabular}

The observed plateau or lag time in the presence of $100 \mu \mathrm{M}$ compound is not significantly different from that observed for control samples. ${ }^{\text {a }}$ Inhibitions are expressed as mean \pm SEM, $n=3-5$. 


\subsection{Synthesis of Ranitidine Analogs Containing 1,8-Naphthalimide and Their Inhibitory Activities} toward $A B$ Aggregation and $A C h E$

Additional ranitidine analogs containing 1,8-naphthalimide were designed and synthesized through Scheme 1 . Their inhibitory activities toward $A \beta$ aggregation are shown in Figure 3, Table 2. All these 1,8-naphthalimide compounds exhibited potent plateau reduction except compound 7 , which lacks one aromatic end group, the inhibitory capacity of which was abrogated. This observation demonstrates that the presence of two aromatic end groups in a molecule is critical for potent $A \beta$ aggregation inhibition. It is also interesting that compounds $\mathbf{9}$ and $\mathbf{1 0}$ with thiazole rings at the other end of the structures demonstrated similar plateau reductions $(61.4 \% \pm 19.7 \%$ and $54.2 \% \pm 5.1 \%$, respectively) to compounds 3 and 6 , which indicates that the furan rings in these 1,8-naphthalimide-derived ranitidine analogs could be replaced by other aromatic rings while keeping similar $A \beta$ aggregation inhibition. As for the substituents on the 1,8-naphthalimide, the plateau reduction of compound $\mathbf{8}$ with a 4-chloro substituent is between the reductions of the unsubstituted derivative (compound 3) and the 3-nitro derivative (compound 6), which suggested that substituents on the naphthalimide group may enhance the plateau reductions.
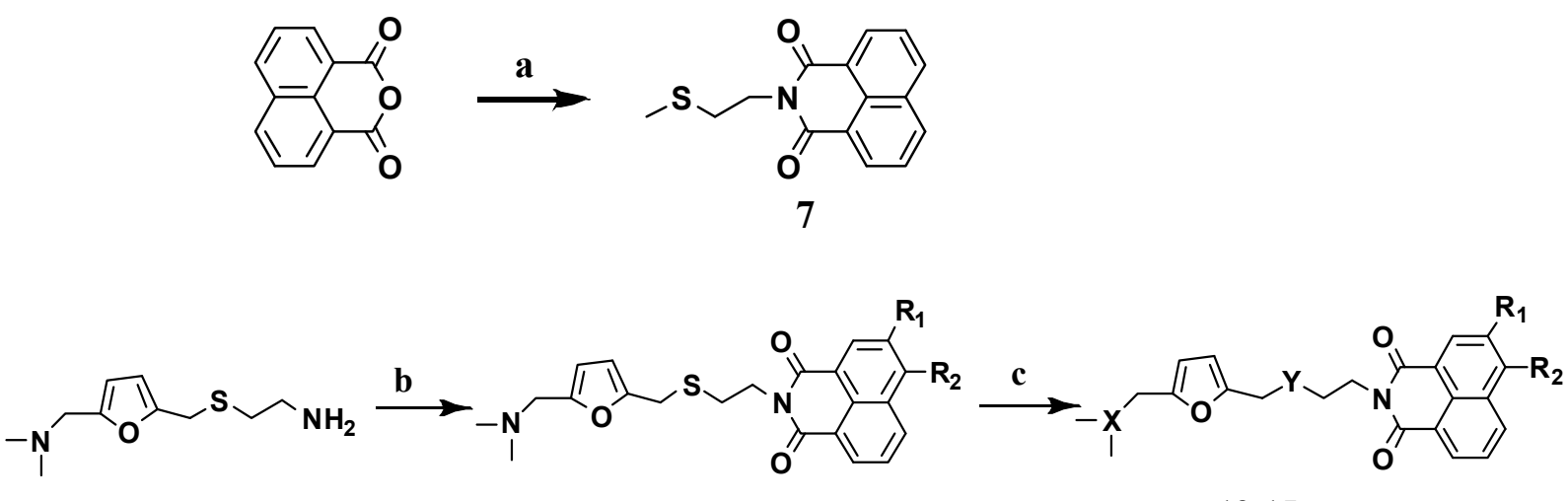

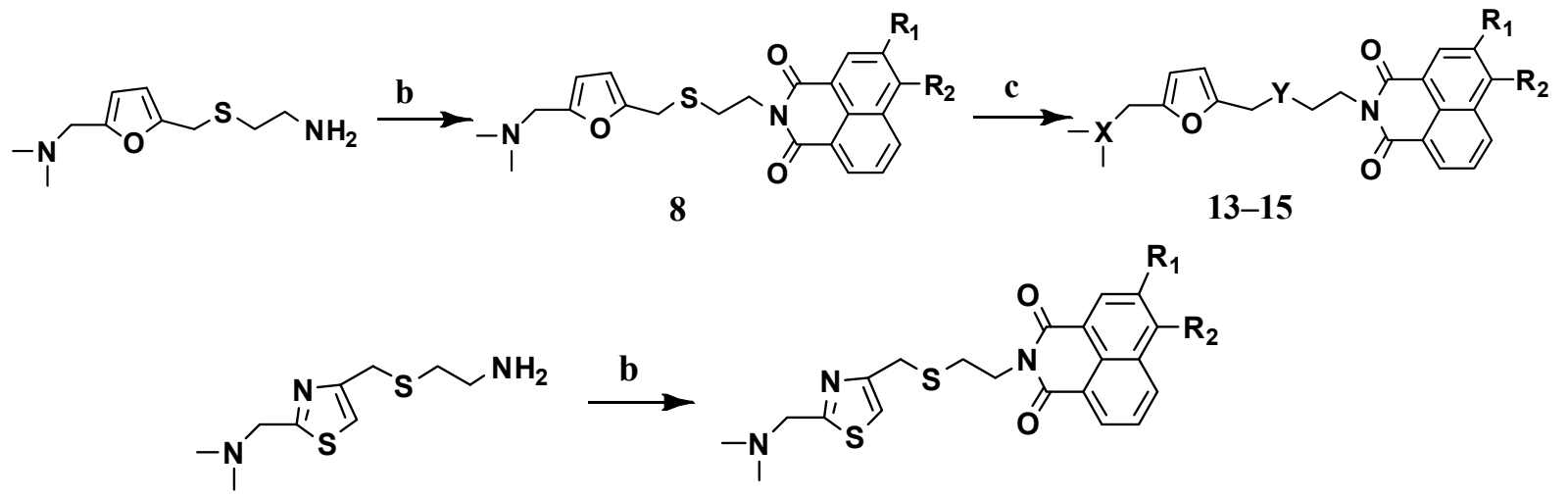

\section{9, 10}

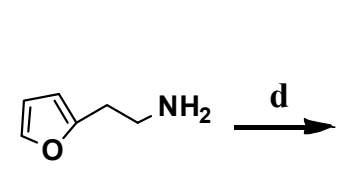<smiles>O=C1c2cccc3cc([N+](=O)[O-])cc(c23)C(=O)N1CCc1ccco1</smiles>

11

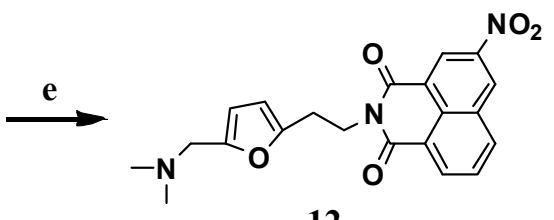

12

Scheme 1. Preparation of ranitidine analogs containing 1,8-naphthalimide (a) 2-(Methylthio)ethylamine, toluene, reflux. 5 hrs. (b) Correspondent 1,8-naphthalic anhydrides, toluene, reflux. 3-5 hrs. (c) $\mathrm{H}_{2} \mathrm{O}_{2}, \mathrm{CH}_{3} \mathrm{CH}_{2} \mathrm{OH}$, room temperature. overnight, (d) 3-nitro-1,8-naphthalic anhydrides, toluene, reflux. $3-5 \mathrm{hrs}$. (e) $\mathrm{NH}\left(\mathrm{CH}_{3}\right)_{2} \bullet \mathrm{HCl}, 37 \% \mathrm{HCHO}, 90{ }^{\circ} \mathrm{C}, 2.5 \mathrm{~h}$. 
<smiles>CSCCN1C(=O)c2cccc3cccc(c23)C1=O</smiles>

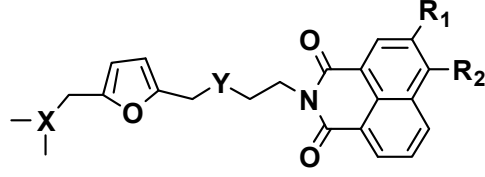

8: $X=N, Y=S, R_{1}=H, R_{2}=C l$

13: $X=N, Y=S=O, R_{1}=N_{2}, R_{2}=H$

14: $X=N, Y=S=O, R_{1}=H, R_{2}=H$

15: $X=N=O, Y=O=S=O, R_{1}=N_{2}, R_{2}=H$

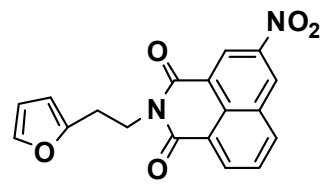

11<smiles>[R]c1cc2c3c(cccc3c1[R])C(=O)N(CCSCc1csc(CN(C)C)n1)C2=O</smiles>

9: $\mathbf{R}_{1}=\mathbf{H}, \mathbf{R}_{\mathbf{2}}=\mathbf{H}$

10: $\mathrm{R}_{1}=\mathrm{NO}_{2}, \mathrm{R}_{2}=\mathrm{H}$

Figure 3. The structure of ranitidine analogs containing 1,8-naphthalimide.

Table 2. The inhibition capabilities of ranitidine analogs containing 1,8-naphthalimide on $A \beta$ monomer aggregation ${ }^{\mathrm{a}}$ and AChE activity.

\begin{tabular}{cccc}
\hline Compound & $\begin{array}{c}\text { Plateau Reduction } \\
\text { (\% Inhibition) }\end{array}$ & $\begin{array}{c}\text { Lag Time Extension } \\
\text { (Fold Increase) }\end{array}$ & $\begin{array}{c}\text { AChE } \\
\left(\mathbf{I C}_{\mathbf{5 0}} \boldsymbol{\mu M}\right)\end{array}$ \\
\hline $\mathbf{7}$ & N.E. & N.E. & N.T. \\
$\mathbf{8}$ & $65.8 \% \pm 3.5 \%$ & N.E. & 1.23 \\
$\mathbf{9}$ & $54.2 \% \pm 5.1 \%$ & N.E. & 2.02 \\
$\mathbf{1 0}$ & $61.4 \% \pm 19.7 \%$ & N.E. & 0.52 \\
$\mathbf{1 1}$ & $60.3 \% \pm 9.8 \%$ & $1.76 \pm 0.61$ & N.T. \\
$\mathbf{1 2}$ & $65.6 \% \pm 4.1 \%$ & $2.25 \pm 0.25$ & 0.36 \\
$\mathbf{1 3}$ & $26.8 \% \pm 10.4 \%$ & N.E. & N.T. \\
$\mathbf{1 4}$ & $20.1 \% \pm 4.6 \%$ & N.E. & N.T. \\
$\mathbf{1 5}$ & $20.4 \% \pm 9.6 \%$ & N.E. & N.T. \\
\hline
\end{tabular}

The observed plateau or lag time in the presence of $100 \mu \mathrm{M}$ compounds is not significantly different from that observed for control samples. N.T.: not tested. ${ }^{\text {a }}$ Inhibitions are expressed as mean $\pm \mathrm{SEM}, n=3-5$.

Compound 11 was further designed and synthesized to improve the lag time extension of these ranitidine analogs since a two-carbon chain in the 1,8-naphthalimide analogs possesses the optimal length for $A \beta$ aggregation inhibition [14]. As expected, this compound provided a significant plateau reduction of $60.3 \% \pm 9.8 \%$ and extended the lag time by $1.76 \pm 0.61$-fold over the control sample.

It should also be noted that compound 6 is a potent $\mathrm{AChE}$ inhibitor $\left(\mathrm{IC}_{50}=0.15 \mu \mathrm{M}\right)$ due to the structural elements of dimethylamine and naphthalimide [11]. In order to revive the $\mathrm{AChE}$ inhibition for compound 11, the dimethyl amino group was added to its structure, leading to compound 12. Compounds 8-10 and $\mathbf{1 2}$ were selected for the evaluation of AChE inhibition. As shown in Table 2, these selected compounds have potent inhibitory activities toward AChE. In particular, compound $\mathbf{1 2}$ possesses a high efficacy as an $\mathrm{AChE}$ inhibitor $\left(\mathrm{IC}_{50}=0.36 \mu \mathrm{M}\right)$. Since both $\mathrm{A} \beta$ aggregation and $\mathrm{AChE}$ are therapeutic targets for $\mathrm{AD}$, these ranitidine analogs could represent a new type of multi-target directed ligands beneficial to the therapy of AD.

However, the oxidation of sulfur (compounds 13-15) significantly impaired the inhibitory activities of these molecules, which may be due to the rigid conformations of the sulfoxide or sulfone molecules. As proposed in the ideal structure of $A \beta$ aggregation inhibitors, a flexible linker is critical for the conformational compatibility to Phe19-Phe20 
in the $A \beta$ peptide in order to facilitate binding to $A \beta$ and interfere with the addition of $A \beta$ monomers to growing aggregates [5]. However, water molecules in the solvents might display a solvation effect via multiple hydrogen bonding interactions and stabilize the conformations of these molecules. As shown in Figure 4, compounds 13-15 in their most energetically favorable computed conformations were aligned together with the help of the Discovery Studio (Dassault Systemes, Waltham, MA) [15], a software application that simulates small molecule and macromolecule systems. The length between the oxygen atoms of sulfoxides or sulfones and the oxygen atoms of the imide groups is only $4.278 \AA$, which is close enough to have hydrogen bonds with one water molecule. These hydrogen bonds could lock the conformation and impede the interactions of these molecules with A $\beta$ peptides.

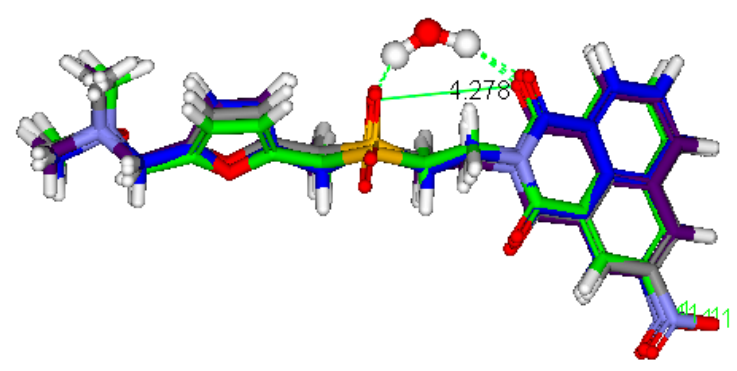

Figure 4. The alignment of 1,8-naphthalimide derivatives in the most energetically favorable computed conformations.

\section{Materials and Methods}

\subsection{Materials}

$\mathrm{A} \beta_{40}$ was purchased from AnaSpec (AnaSpec, Fremont, CA, USA) and stored in lyophilized form at $-20{ }^{\circ} \mathrm{C}$. Thioflavin $\mathrm{T}(\mathrm{ThT})$ and electric eel AChE were obtained from Sigma (Sigma-Aldrich, St. Louis, MO, USA). Bovine serum albumin (BSA) and dimethyl sulfoxide (DMSO) were purchased from EMD Biosciences (EMD Biosciences, San Diego, CA, USA). Tris- $\mathrm{HCl}$ ( $\mathrm{pH}$ 8.0) was prepared using Tris base, purchased from Promega (Promega, Madison, WI, USA) and Tris hydrochloride, purchased from EMD (EMD, Burlington, MA, USA).

\subsection{Chemical Synthesis}

Melting points were determined on an Electrothermal ${ }^{\circledR}$ melting point apparatus (ColeParmer, Vermon Hills, IL, USA) and are uncorrected. ${ }^{1} \mathrm{H}-\mathrm{NMR}$ spectra were obtained on a Mercury VX-300 spectrometer (Varian, Palo Alto, CA, USA), using deuterochloroform $\left(\mathrm{CDCl}_{3}\right)$ as the solvent. Most chemicals were purchased from Acros Organics (Fair Lawn, NJ, USA) and TCI America chemicals (Portland, OR, USA). Mass spectrometry was performed utilizing a VG Analytical $70 \mathrm{~S}$ magnetic sector mass spectrometer (Waters, Milford, MA, USA). Chromatography was performed using Geduran ${ }^{\circledR}$ silica gel $(40-63 \mu \mathrm{m})$.

\subsubsection{General Procedure for Compounds $\mathbf{1}-\mathbf{1 0}$}

To a suspension of 1,8-naphthalic anhydride $(3.0 \mathrm{~g}, 15 \mathrm{mmol})$ in toluene $(100 \mathrm{~mL})$, the corresponding reactants $(15 \mathrm{mmol})$ were added dropwise. The reaction mixture was refluxed with a condenser and a Dean-Stark trap for 5 hours and then evaporated to yellow solid, which was recrystallized with toluene $(60 \mathrm{~mL})$ to yield products. The structural information of compounds 1-6 is available in our previous paper [11].

2-(2-(Methylthio)ethyl)-5-nitro-1H-benzo[de]isoquinoline-1,3(2H)-dione(7) Melting point (mp): 153-154 ${ }^{\circ} \mathrm{C}$; $1 \mathrm{H} \mathrm{NMR}\left(300 \mathrm{MHz}, \mathrm{CDCl}_{3}\right) \delta 2.19\left(\mathrm{~s}, 3 \mathrm{H}, \mathrm{SCH}_{3}\right), 2.82(\mathrm{t}, \mathrm{J}=7.1$, $\left.2 \mathrm{H}, \mathrm{SCH}_{2} \mathrm{CH}_{2}\right), 4.38\left(\mathrm{t}, \mathrm{J}=7.1,2 \mathrm{H}, \mathrm{CH}_{2} \mathrm{CH}_{2} \mathrm{NH}\right), 7.89(\mathrm{t}, \mathrm{J}=7.5,1 \mathrm{H}, \mathrm{ArH}), 8.8(\mathrm{~d}, \mathrm{~J}=7.5$, $1 \mathrm{H}, \operatorname{ArH}), 8.72(\mathrm{~d}, \mathrm{~J}=7.5,1 \mathrm{H}, \operatorname{ArH}), 9.08(\mathrm{~d}, \mathrm{~J}=7.5,1 \mathrm{H}, \operatorname{ArH}), 9.27(\mathrm{~d}, \mathrm{~J}=7.5,1 \mathrm{H}, \operatorname{ArH})$. HRMS: Obs. $\mathrm{M}+\mathrm{H}, 316.0519$. Calc. $\mathrm{M}+\mathrm{H}, 316.0518$. 
6-Chloro-2-(2-(((5-((dimethylamino)methyl)furan-2-yl)methyl)thio)ethyl)-1H-benzo [de]isoquinoline-1,3(2H)-dione(8) mp: 98-99 ${ }^{\circ} \mathrm{C}$; $\left.1 \mathrm{H} \mathrm{NMR} \mathrm{(300} \mathrm{MHz,} \mathrm{CDCl}_{3}\right) \delta 2.26$ $\left(\mathrm{s}, 6 \mathrm{H}, \mathrm{N}\left(\mathrm{CH}_{3}\right)_{2}\right), 2.84\left(\mathrm{t}, \mathrm{J}=7.1,2 \mathrm{H}, \mathrm{SCH}_{2} \mathrm{CH}_{2}\right), 3.45\left(\mathrm{~s}, 2 \mathrm{H}, \mathrm{CCH}_{2} \mathrm{~S}\right), 3.84(\mathrm{~s}, 2 \mathrm{H}$, $\left.\left(\mathrm{CH}_{3}\right)_{2} \mathrm{NCH}_{2}\right), 4.37\left(\mathrm{t}, \mathrm{J}=7.1,2 \mathrm{H}, \mathrm{CH}_{2} \mathrm{CH}_{2} \mathrm{~N}\right), 6.11(\mathrm{~d}, \mathrm{~J}=7.5,1 \mathrm{H}, \mathrm{ArH}), 6.25(\mathrm{~d}, \mathrm{~J}=7.5$, $1 \mathrm{H}, \mathrm{ArH}), 7.40(\mathrm{~m}, 2 \mathrm{H}, \mathrm{ArH}), 8.48(\mathrm{~d}, \mathrm{~J}=7.5,1 \mathrm{H}, \mathrm{ArH}), 8.63(\mathrm{~d}, \mathrm{~J}=7.5,1 \mathrm{H}, \mathrm{ArH}), 8.65$ (d, J = 7.5, 1H, ArH). HRMS: Obs. M+H, 429.1039. Calc. $\mathrm{M}+\mathrm{H}, 429.1039$.

2-(2-((2-((Dimethylamino)methyl)thiazol-4-yl)methylthio)ethyl)-1H-benzo[de]iso quinoline-1,3(2H)-dione (9) mp: $116-118{ }^{\circ} \mathrm{C}$; $1 \mathrm{H} \mathrm{NMR}\left(300 \mathrm{MHz}, \mathrm{CDCl}_{3}\right) \delta 2.35(\mathrm{~s}, 6 \mathrm{H}$, $\left.\mathrm{N}\left(\mathrm{CH}_{3}\right)_{2}\right), 2.83\left(\mathrm{t}, \mathrm{J}=7.1,2 \mathrm{H}, \mathrm{SCH}_{2} \mathrm{CH}_{2}\right), 3.77\left(\mathrm{~s}, 2 \mathrm{H}, \mathrm{CCH}_{2} \mathrm{~S}\right), 3.97\left(\mathrm{~s}, 2 \mathrm{H},\left(\mathrm{CH}_{3}\right)_{2} \mathrm{NCH}_{2}\right)$, 4.42(t, J = 7.1, 2H, $\left.\mathrm{CH}_{2} \mathrm{CH}_{2} \mathrm{NH}\right), 7.28(\mathrm{~s}, 1 \mathrm{H}, \mathrm{ArH}), 7.77(\mathrm{t}, \mathrm{J}=7.5,2 \mathrm{H}, \mathrm{ArH}), 8.23(\mathrm{~d}, \mathrm{~J}=7.5$, 2H, ArH), 8.62 (d, J = 7.5, 2H, ArH). HRMS: Obs. M+H, 412.1152. Calc. M+H, 412.1153.

2-(2-(((2-((Dimethylamino)methyl)thiazol-4-yl)methyl)thio)ethyl)-5-nitro-1H-benzo[de]isoquinoline-1,3(2H)-dione (10) mp: 124-125 ${ }^{\circ} \mathrm{C} ; 1 \mathrm{H}$ NMR (300 MHz, CDCl3) $\delta 2.36$ $\left(\mathrm{s}, 6 \mathrm{H}, \mathrm{N}\left(\mathrm{CH}_{3}\right)_{2}\right), 2.84\left(\mathrm{t}, \mathrm{J}=7.1,2 \mathrm{H}, \mathrm{SCH}_{2} \mathrm{CH}_{2}\right), 3.78\left(\mathrm{~s}, 2 \mathrm{H}, \mathrm{CCH}_{2} \mathrm{~S}\right)$, $3.96\left(\mathrm{~s}, 2 \mathrm{H},(\mathrm{CH} 3)_{2} \mathrm{NCH}_{2}\right), 4.44\left(\mathrm{t}, \mathrm{J}=7.1,2 \mathrm{H}, \mathrm{CH}_{2} \mathrm{CH}_{2} \mathrm{NH}\right), 7.29(\mathrm{~s}, 1 \mathrm{H}, \mathrm{ArH}), 8.23$ $(\mathrm{t}, \mathrm{J}=7.5,1 \mathrm{H}, \mathrm{ArH}), 8.28(\mathrm{~d}, \mathrm{~J}=7.5,1 \mathrm{H}, \mathrm{ArH}), 8.82(\mathrm{~d}, \mathrm{~J}=7.5,1 \mathrm{H}, \mathrm{ArH}), 8.87(\mathrm{~d}, \mathrm{~J}=7.5,1 \mathrm{H}$, ArH), 9.35 (d, J = 1.5, 1H, ArH). HRMS: Obs. M+H, 456.5409. Calc. M+H, 456. 5409.

\subsubsection{General Procedure for Compound 12}

To a suspension of 3-nitro-1,8-naphthalic anhydride $(4 \mathrm{mmol})$ in toluene $(50 \mathrm{~mL})$, a solution of 2-furan-2-yl-ethanolamine ( $4 \mathrm{mmol}$ ) in ethanol was added dropwise. The reaction mixture was refluxed with a condenser and a Dean-Stark trap for 6 hours and then was evaporated under reduced pressure. The resulting residue was purified by column chromatography. The silica gel was first conditioned with dichloromethane, and then the product was eluted with 50:1 dichloromethane/methanol. Evaporation of the solvent yielded compound 11. Dimethylamine hydrochloride $(1.2 \mathrm{mmol})$ and compound $11(0.6 \mathrm{mmol})$ were added to a stirred $37 \%$ formaldehyde solution $(0.12 \mathrm{~mol})$ under a nitrogen atmosphere. The solution was heated from $25^{\circ} \mathrm{C}$ to $90^{\circ} \mathrm{C}$ for 20 hours and then was allowed to cool to room temperature, transferred to a separatory funnel, and then extracted with $20 \mathrm{~mL}$ of dichloromethane. The aqueous layer was stirred with a $\mathrm{Na}_{2} \mathrm{CO}_{3}$-saturated solution $(20 \mathrm{ml})$. The mixture was extracted with dichloromethane $(10 \mathrm{~mL}$ for three times. The organic solution was washed with distilled water, dried over $\mathrm{MgSO}_{4}$, and concentrated to dryness. The resulting residue was purified by vacuum distillation to yield compound 12 .

2-(2-(5-((Dimethylamino)methyl)furan-2-yl)ethyl)-5-nitro-1H-benzo[de]isoquino line1,3(2H)-dione (11) mp: 85-87 ${ }^{\circ} \mathrm{C} ; 1 \mathrm{H} \mathrm{NMR}\left(300 \mathrm{MHz}, \mathrm{CDCl}_{3}\right) \delta 2.24\left(\mathrm{~s}, 6 \mathrm{H}, \mathrm{N}\left(\mathrm{CH}_{3}\right)_{2}\right.$, $\delta 3.0\left(\mathrm{t}, \mathrm{J}=7.1,2 \mathrm{H}, \mathrm{CH}_{2} \mathrm{CH}_{2} \mathrm{~N}\right), 3.39\left(\mathrm{~s}, 2 \mathrm{H},\left(\mathrm{CH}_{3}\right)_{2} \mathrm{NCH}_{2}\right), 4.49\left(\mathrm{t}, \mathrm{J}=7.1,2 \mathrm{H}, \mathrm{CH}_{2} \mathrm{CH}_{2} \mathrm{~N}\right)$, $5.99(\mathrm{~d}, \mathrm{~J}=7.5,1 \mathrm{H}, \mathrm{ArH}), 6.06(\mathrm{t}, \mathrm{J}=7.5,1 \mathrm{H}, \mathrm{ArH}), 7.94(\mathrm{t}, \mathrm{J}=7.5,1 \mathrm{H}, \mathrm{ArH}), 8.43(\mathrm{~d}, \mathrm{~J}=7.5$, $1 \mathrm{H}, \mathrm{ArH}), 8.76(\mathrm{~d}, \mathrm{~J}=7.5,1 \mathrm{H}, \mathrm{ArH}), 9.13(\mathrm{~d}, \mathrm{~J}=1.5,1 \mathrm{H}, \mathrm{ArH}), 9.29(\mathrm{~d}, \mathrm{~J}=1.5,1 \mathrm{H}, \operatorname{ArH})$. HRMS: Obs. M+H, 394.1404. Calc. M+H, 394.1403.

2-(2-(furan-2-yl)ethyl)-5-nitro-1H-benzo[de]isoquinoline-1,3(2H)-dione (12) mp:182$183{ }^{\circ} \mathrm{C} ; 1 \mathrm{H} \mathrm{NMR}\left(300 \mathrm{MHz}, \mathrm{CDCl}_{3}\right) \delta 3.10\left(\mathrm{t}, \mathrm{J}=7.1,2 \mathrm{H}, \mathrm{CH}_{2} \mathrm{CH}_{2} \mathrm{~N}\right), 4.49(\mathrm{t}, \mathrm{J}=7.1,2 \mathrm{H}$, $\left.\mathrm{CH}_{2} \mathrm{CH}_{2} \mathrm{~N}\right), 6.09(\mathrm{~d}, \mathrm{~J}=7.5,1 \mathrm{H}, \mathrm{ArH}), 6.83(\mathrm{t}, \mathrm{J}=7.5,1 \mathrm{H}, \mathrm{ArH}), 7.31(\mathrm{~d}, \mathrm{~J}=7.5,1 \mathrm{H}, \mathrm{ArH})$, 7.95(t, J = 7.5, 1H, ArH), 8.82(d, J = 7.5, 1H, ArH), 8.77(d, J = 7.5, 1H, ArH), 9.14(d, J = 1.5, $1 \mathrm{H}, \mathrm{ArH}), 9.31(\mathrm{~d}, \mathrm{~J}=1.5,1 \mathrm{H}, \mathrm{ArH})$. HRMS: Obs. $\mathrm{M}+\mathrm{H}, 336.0747$. Calc. $\mathrm{M}+\mathrm{H}, 336.0746$.

\subsubsection{General Procedure for Compounds 13-15}

A solution of compound $6(0.5 \mathrm{mmol})$ in glacial acetic acid $(20 \mathrm{~mL})$ was treated with $35 \%$ hydrogen peroxide $(38 \mu \mathrm{L})$ in ice bath. The mixture was stirred while warming to room temperature overnight and then was evaporated under reduced pressure. The resulting residue was purified by flash column chromatography using dichloromethane/methanol mobile system. Evaporation of the solvent yielded products compound 13 and 15. Compound 14 was synthesized from compound 3 using the same procedure.

2-(2-(((5-((Dimethylamino)methyl)furan-2-yl)methyl)sulfinyl)ethyl)-5-nitro-1H-benzo[de]isoquinoline-1,3(2H)-dione(13) mp: $106.5-108{ }^{\circ} \mathrm{C} ; 1 \mathrm{H} \mathrm{NMR}\left(300 \mathrm{MHz}, \mathrm{CDCl}_{3}\right)$ 
$\delta 2.28\left(\mathrm{~s}, 6 \mathrm{H}, \mathrm{N}\left(\mathrm{CH}_{3}\right)_{2}\right), 3.10\left(\mathrm{t}, \mathrm{J}=7.1,2 \mathrm{H}, \mathrm{SCH}_{2} \mathrm{CH}_{2}\right), 3.51\left(\mathrm{~s}, 2 \mathrm{H}, \mathrm{CCH}_{2} \mathrm{~S}\right), 4.17(\mathrm{~s}, 2 \mathrm{H}$, $\left.\left(\mathrm{CH}_{3}\right)_{2} \mathrm{NCH}_{2}\right), 4.68\left(\mathrm{t}, \mathrm{J}=7.1,2 \mathrm{H}, \mathrm{CH}_{2} \mathrm{CH}_{2} \mathrm{~N}\right), 6.24(\mathrm{~d}, \mathrm{~J}=7.5,1 \mathrm{H}, \mathrm{ArH}), 6.39(\mathrm{~d}, \mathrm{~J}=7.5,1 \mathrm{H}$, ArH), $7.95(\mathrm{t}, \mathrm{J}=7.5,1 \mathrm{H}, \mathrm{ArH}), 8.45(\mathrm{~d}, \mathrm{~J}=7.5,1 \mathrm{H}, \mathrm{ArH}), 8.80(\mathrm{~d}, \mathrm{~J}=7.5,1 \mathrm{H}, \mathrm{ArH}), 9.16(\mathrm{~d}$, $\left.\mathrm{J}=1.5,1 \mathrm{H}, \mathrm{NO}_{2} \mathrm{ArH}\right), 9.34\left(\mathrm{~d}, \mathrm{~J}=1.5,1 \mathrm{H}, \mathrm{NO}_{2} \mathrm{ArH}\right)$. HRMS: Obs. $\mathrm{M}+\mathrm{H}, 456.1232$. Calc. $\mathrm{M}+\mathrm{H}, 456.1229$.

2-(2-(((5-((Dimethylamino)methyl)furan-2-yl)methyl)sulfinyl)ethyl)-1H-benzo[de] isoquinoline-1,3(2H)-dione(14) mp: 117-119 ${ }^{\circ} \mathrm{C}$; $1 \mathrm{H} \mathrm{NMR}\left(300 \mathrm{MHz}, \mathrm{CDCl}_{3}\right) \delta 2.22(\mathrm{~s}, 6 \mathrm{H}$, $\left.\mathrm{N}\left(\mathrm{CH}_{3}\right)_{2}\right), 3.09\left(\mathrm{t}, \mathrm{J}=7.1,2 \mathrm{H}, \mathrm{SCH}_{2} \mathrm{CH}_{2}\right), 3.43\left(\mathrm{~s}, 2 \mathrm{H}, \mathrm{CCH}_{2} \mathrm{~S}\right), 4.18\left(\mathrm{~s}, 2 \mathrm{H},\left(\mathrm{CH}_{3}\right)_{2} \mathrm{NCH}_{2}\right)$, $4.64\left(\mathrm{t}, \mathrm{J}=7.1,2 \mathrm{H}, \mathrm{CH}_{2} \mathrm{CH}_{2} \mathrm{~N}\right), 6.19(\mathrm{~d}, \mathrm{~J}=7.5,1 \mathrm{H}, \mathrm{ArH}), 6.39(\mathrm{~d}, \mathrm{~J}=7.5,1 \mathrm{H}, \mathrm{ArH}), 7.76(\mathrm{t}$, $\mathrm{J}=7.5,2 \mathrm{H}, \operatorname{ArH}), 8.24(\mathrm{~d}, \mathrm{~J}=7.5,2 \mathrm{H}, \mathrm{ArH}), 8.62(\mathrm{~d}, \mathrm{~J}=7.5,1 \mathrm{H}, \mathrm{ArH})$. HRMS: Obs. $\mathrm{M}+\mathrm{H}$, 411.1382. Calc. $\mathrm{M}+\mathrm{H}, 411.1378$.

N,N-Dimethyl-1-(5-((2-(5-nitro-1,3-dioxo-1H-benzo[de]isoquinolin-2(3H)-yl)ethyl) su lfonyl)methyl)furan-2-yl)methanamine oxide(15) mp: $138-40{ }^{\circ} \mathrm{C} ; 1 \mathrm{H}$ NMR $\left(300 \mathrm{MHz}, \mathrm{CDCl}_{3}\right) \delta 3.18\left(\mathrm{~s}, 6 \mathrm{H}, \mathrm{N}\left(\mathrm{CH}_{3}\right)_{2}\right), 3.47\left(\mathrm{t}, 2 \mathrm{H}, \mathrm{SO}_{2} \mathrm{CH}_{2} \mathrm{CH}_{2}\right), 4.47(\mathrm{~s}, 2 \mathrm{H}$, $\left.\left(\mathrm{CH}_{3}\right)_{2} \mathrm{NCH}_{2}\right), 4.58\left(\mathrm{~s}, 2 \mathrm{H}, \mathrm{CCH}_{2} \mathrm{SO}_{2}\right), 4.71\left(\mathrm{t}, \mathrm{J}=7.1,2 \mathrm{H}, \mathrm{CH}_{2} \mathrm{CH}_{2} \mathrm{~N}\right), 6.69(\mathrm{~s}, 2 \mathrm{H}$, ArH), $7.98(\mathrm{t}, \mathrm{J}=7.5,1 \mathrm{H}, \mathrm{ArH}), 8.47(\mathrm{~d}, \mathrm{~J}=7.5,1 \mathrm{H}, \mathrm{ArH}), 8.82(\mathrm{~d}, \mathrm{~J}=7.5,1 \mathrm{H}, \operatorname{ArH})$, $9.17(\mathrm{~d}, \mathrm{~J}=7.5,1 \mathrm{H}, \mathrm{ArH}), 9.34$ (d, $\mathrm{J}=7.5,1 \mathrm{H}, \mathrm{ArH})$. HRMS: Obs. $\mathrm{M}+\mathrm{H}, 488.1141$. Calc. $\mathrm{M}+\mathrm{H}, 488.1127$.

\subsection{Biological Assays}

\subsubsection{Preparation of $A \beta$ Monomers}

Lyophilized $\mathrm{A} \beta$ peptide was reconstituted in $50 \mathrm{mM} \mathrm{NaOH}$ at a concentration of $2 \mathrm{mg} / \mathrm{mL}$ and purified via size-exclusion chromatography (SEC) on a Superdex $75 \mathrm{HR}$ 10/300 column (Cytiva, Marlborough, MA) using a running buffer of $40 \mathrm{mM}$ Tris- $\mathrm{HCl}$ ( $\mathrm{pH}$ 8.0). Bovine serum albumin (BSA) $(2 \mathrm{mg} / \mathrm{mL})$ was employed as a pretreatment to reduce nonspecific $A \beta$ interaction with the dextran matrix of the column. The elution profile showed a characteristic peak corresponding to monomeric $A \beta$. The concentrations of eluted $A \beta$ monomer fractions were determined with a calculated extinction coefficient of $1450 \mathrm{M}^{-1} \mathrm{~cm}^{-1}$ at $276 \mathrm{~nm}$. Purified $\mathrm{A} \beta$ monomer samples were used fresh or stored at $4{ }^{\circ} \mathrm{C}$ for up to 4 days.

\subsubsection{Preparation of Ranitidine Analogs}

All compounds were dissolved in DMSO at $5 \mathrm{mM}$ and stored at $-20^{\circ} \mathrm{C}$. Immediately prior to experimentation, stock solutions were diluted into DMSO such that subsequent dilution to $100 \mu \mathrm{M}$ ranitidine analog yielded $2 \%(v / v)$ DMSO in the final reaction solution. DMSO $(2 \% v / v)$ was added to control reactions run in parallel.

\subsubsection{ThT Fluorescence Assay}

SEC-purified $\mathrm{A} \beta$ monomer was diluted to $40 \mu \mathrm{M}$ in $40 \mathrm{mM}$ Tris- $\mathrm{HCl}$ (pH 8.0) and agitated (vortex, $800 \mathrm{rpm}, 25^{\circ} \mathrm{C}$ ) without (control) or with $100 \mu \mathrm{M}$ ranitidine analogs. Periodically, a $20-\mu \mathrm{L}$ aliquot was removed and combined with $140 \mu \mathrm{L}$ of $10 \mu \mathrm{M}$ ThT. Fluorescence (excitation $=450 \mathrm{~nm}$, emission $=470-500 \mathrm{~nm}$ ) was evaluated using a PerkinElmer LS-45 luminescence spectrometer (Waltham, MA, USA). Fluorescence values were calculated as the integrated area under the emission curve with baseline (ThT alone) subtraction and plotted vs. aggregation time. Each compound was evaluated using at least three independent experiments.

\subsubsection{AChE Inhibition Assay}

The AChE inhibition assay was modified based on the method of Ellman et al. [16] in a 24-well plate format at $37^{\circ} \mathrm{C}$. Assays were performed in $0.1 \mathrm{M}$ sodium phosphate ( $\mathrm{pH}$ 8.0), containing $200 \mu \mathrm{M}$ acetylthiocholine, $100 \mu \mathrm{M}$ dithiobisnitrobenzoic acid, and 0.005 units of AChE in a final volume of $3000 \mu \mathrm{L}$. The reaction was initiated by the addition of acetylthiocholine, and the formation of a product was monitored by measuring absorbance at $412 \mathrm{~nm}$. The $\mathrm{IC}_{50}$ values were determined by nonlinear regression analysis of the 
concentration-response curves generated. Each compound was evaluated using at least three independent experiments.

\section{Conclusions}

In this study, a series of multi-target ranitidine analogs containing cyclic imide isosteres was explored through rationally designed structural modifications. Of particular note, the analogs with 1,8-naphthamide resulted in potent inhibition of $A \beta$ aggregation. While improving the $A \beta$ aggregation inhibition, these structural modifications also retained high efficacy as AChE inhibitors. These results imply that this series of ranitidine analogs represents a new type of MTDLs with inhibitory activities of both $A \beta$ aggregation and $\mathrm{AChE}$. The structural elements in these analogs can be further explored to develop more effective MTDLs for the pharmaceutical treatment of AD.

Author Contributions: Conceptualization, J.G., J.C. and M.A.M.; methodology, J.G., C.S., J.-H.T., M.A.M., and A.V.T.J. All authors have read and agreed to the published version of the manuscript.

Funding: This research was supported by the National Institute of General Medical Sciences at the National Institutes of Health via funding through the Centers of Biomedical Research Excellence Program (COBRE, P20GM103641 to M.A.M.).

Conflicts of Interest: The authors declare no conflict of interest.

\section{References}

1. Murphy, M.P.; Le Vine, H., 3rd. Alzheimer's disease and the amyloid-beta peptide. J. Alzheimers Dis. 2010, 19, 311-323. [CrossRef] [PubMed]

2. Walsh, D.M.; Selkoe, D.J. A beta oligomers-A decade of discovery. J. Neurochem. 2007, 101, 1172-1184. [CrossRef] [PubMed]

3. Güntert, A.; Döbeli, H.; Bohrmann, B. High sensitivity analysis of amyloid-beta peptide composition in amyloid deposits from human and PS2APP mouse brain. Neuroscience 2006, 143, 461-475. [CrossRef] [PubMed]

4. Tjernberg, L.O. Arrest of beta-amyloid fibril formation by a pentapeptide ligand. J. Biol. Chem. 1996, 271, 8545-8548. [CrossRef] [PubMed]

5. Reinke, A.A.; Gestwicki, J.E. Structure-activity Relationships of Amyloid Beta-aggregation Inhibitors Based on Curcumin: Influence of Linker Length and Flexibility. Chem. Biol. Drug Des. 2007, 70, 206-215. [CrossRef] [PubMed]

6. Lu, J. Structure-Based Peptide Inhibitor Design of Amyloid-beta Aggregation. Front. Mol. Neurosci. 2019, 12, 54. [CrossRef] [PubMed]

7. Shuaib, S.; Goyal, B. Scrutiny of the mechanism of small molecule inhibitor preventing conformational transition of amyloidbeta42 monomer: Insights from molecular dynamics simulations. J. Biomol. Struct. Dyn. 2018, 36, 663-678. [CrossRef] [PubMed]

8. Nie, Q.; Du, X.G.; Geng, M.Y. Small molecule inhibitors of amyloid beta peptide aggregation as a potential therapeutic strategy for Alzheimer's disease. Acta. Pharmacol. Sin. 2011, 32, 545-551. [CrossRef] [PubMed]

9. Lee, J.H. Donepezil across the spectrum of Alzheimer's disease: Dose optimization and clinical relevance. Acta Neurol. Scand. 2015, 131, 259-267. [CrossRef] [PubMed]

10. Cavalli, A. Multi-target-directed ligands to combat neurodegenerative diseases. J. Med. Chem. 2008, 51, 347-372. [CrossRef] [PubMed]

11. Gao, J.; Midde, N.; Zhu, J.; Terry, A.V.; McInnes, C.; Chapman, J.M. Synthesis and biological evaluation of ranitidine analogs as multiple-target-directed cognitive enhancers for the treatment of Alzheimer's disease. Bioorg. Med. Chem. Lett. 2016, 26, 5573-5579. [CrossRef] [PubMed]

12. Goedert, M.; Spillantini, M.G. A century of Alzheimer's disease. Science 2006, 314, 777-781. [CrossRef] [PubMed]

13. Soto-Ortega, D.D. Inhibition of amyloid-beta aggregation by coumarin analogs can be manipulated by functionalization of the aromatic center. Bioorg. Med. Chem. 2011, 19, 2596-2602. [CrossRef]

14. Gao, J.; Chapman, J. Discovery and Characterization of Novel Naphthalimide Analogs as Potent Multitargeted Directed Ligands against Alzheimer's Disease. Drug. Dev. Res. 2020. [CrossRef] [PubMed]

15. Discovery Studio 2.5; Dassault Systemes: Waltham, MA, USA, 2009.

16. Ellman, G.L.; Callaway, E. Erythrocyte Cholinesterase-levels in Mental Patients. Nature 1961, 192, 1216. [CrossRef] [PubMed] 